\title{
Purification and Characterization of Betaine Aldehyde Dehydrogenase from Pseudomonas aeruginosa $\mathrm{A}-16^{\dagger}$
}

\author{
Toru Nagasawa, Yoshiyasu Kawabata, Yoshiki Tani \\ and Koichi OGATA
}

Department of Agricultural Chemistry, Kyoto University, Kyoto

Received March 11, 1976

\begin{abstract}
The significant betaine aldehyde dehydrogenase activity was found in the cells of $P_{\text {seu- }}$ domonas aeruginosa A-16. The enzyme was inducibly formed and accumulated in the presence of choline, acetylcholine or betaine in the medium. The enzyme was purified approximately 620 -fold with an overall recovery of $2.6 \%$ and proved to be homogeneous by ultracentrifugation. The molecular weight of the enzyme was determined as approximately 145,000 by gel filtration method. The enzyme had an isoelectric point around $\mathrm{pH} 5.1$. The enzyme was quite specific for its substrate, betaine aldehyde. Both NADP and NAD functioned as coenzyme. The estimated values of $\mathrm{Km}$ at pH 7.4 and $25^{\circ} \mathrm{C}$ were $3.8 \times 10^{-4} \mathrm{M}$ for betaine aldehyde, $8.9 \times 10^{-5} \mathrm{M}$ for NADP and $2.2 \times 10^{-4} \mathrm{M}$ for NAD.
\end{abstract}

The liver enzyme system involved in the oxidation of choline to betaine has been studied by several groups of workers to characterize the function and the mechanism of action. The first oxidizing enzyme for choline is choline dehydrogenase, presenting in the mitochondria of rat liver. ${ }^{1 \sim 4)}$ Betaine aldehyde dehydrogenase (EC 1.2.1.8), the second oxidizing enzyme in the choline oxidation, was found in rat liver by Bernheim and Bernheim. ${ }^{5}$

These studies on choline oxidation have so far been restricted to the preparation from mammalian liver. The microbial conversion of choline to betaine has not been clarified enzymatically, ${ }^{6}$ though many bacteria can grow on choline as the sole carbon and nitrogen source. $^{7)}$

Recently the authors reported that a choline dehydrogenase was present in the particulate fraction of the cell-free extract of Pseudomonas aeruginosa $\mathrm{A}-16{ }^{81}$ With the advance of the study, it was also found that a betaine aldehyde dehydrogenase was present in the cells of the bacterium grown on choline.

With a view to extensive study of the

\footnotetext{
$t$ For the preceding paper in the series, see Refs. 8,
} 13,14 and 15 ). microbial choline oxidation, the purification and the characterization of the betaine aldehyde dehydrogenase are undertaken in this paper.

\section{MATERIALS AND METHODS}

Chemicals. The following chemicals were purchased from Boehringer Co., Mannheim: cytochrome $c$ (horse heart), chymotrypsinogen A (bovine pancreas), catalase and alcohol dehydrogenase (yeast). NAD and NADP were obtained from Oriental Yeast Co., Ltd. and freshly prepared solutions were used in all experiments. Betaine aldehyde was prepared from 2,2-diethoxy-ethyltrimethylammonium iodide, purchased from Aldrich Chemical Co., as described by Rothschild and Guz-Barron. ${ }^{92}$ The stock solution of betaine aldehyde was approximately $400 \mathrm{~mm}$ and was stored at $-20^{\circ} \mathrm{C}$. Ampholytes for isoelectric focusing were obtained from LKB-PRODUKTER-AB.

Microorganism and culture. Pseudomonas aeruginosa A-16 was used. Culture was carried out aerobically at $28^{\circ} \mathrm{C}$ in a medium containing $1.5 \%$ choline chloride, $0.3 \%$ yeast extract, $0.1 \% \mathrm{~K}_{2} \mathrm{HPO}_{4}$, $0.1 \% \mathrm{NaCl}$, and $0.05 \% \mathrm{MgSO}_{4} \cdot 7 \mathrm{H}_{2} \mathrm{O}$ at pH 7.0 . After 72 -hr cultivation, cells were harvested by centrifugation, washed twice with physiological saline, and stored at $-20^{\circ} \mathrm{C}$ as frozen paste until used.

Assay of enzyme activity. The reaction mixture contained $125 \mu$ moles of potassium phosphate buffer 
(pH 7.4), $0.78 \mu$ mole of NADP, $2.5 \mu$ moles of betaine aldehyde and a suitable amount of enzyme in a total volume of $2.58 \mathrm{ml}$. The reaction was initiated at $30^{\circ} \mathrm{C}$ by the addition of the enzyme and the appearance of NADPH was measured at $340 \mathrm{~nm}$, spectrophotometrically.

One unit of the enzyme activity was defined as the amount of the enzyme that catalyzes the appearance of $1 \mu$ mole of NADPH per min under the above condition. The specific activity was expressed as units per $\mathrm{mg}$ of protein.

Protein determination. Protein was determined by the procedure of Lowry et al., ${ }^{10)}$ or from the absorbance at $280 \mathrm{~nm}$ with the assumption that $0.1 \%$ protein solution in $1 \mathrm{~cm}$ light path would yield an absorbance of 1.0 .

Instruments. Absorbance was measured in a Hitachi double-beam spectrophotometer model 124 equipped with a recorder and a constant temperature cell compartment. The purity and sedimentation coefficient were determined with a Spinco Model E ultracentrifuge at $20^{\circ} \mathrm{C}$ and $59,780 \mathrm{rev} . / \mathrm{min}$.

Molecular weight estimation. The molecular weight of the enzyme was estimated by the method of Andrews, ${ }^{11)}$ using a $3 \times 80 \mathrm{~cm}$ column of Sephadex G-200 in $0.01 \mathrm{M}$ potassium phosphate buffer (pH 7.4) containing $0.1 \mathrm{M} \mathrm{KCl}$. Cytochrome $c$, chymotrypsinogen A, egg albumin, alcohol dehydrogenase and catalase, all at $2 \mathrm{mg} / \mathrm{ml}$ were used as molecular weight markers.

\section{RESULTS}

\section{Formation of betaine aldehyde dehydrogenase}

The betaine aldehyde dehydrogenase of Pseudomonas aeruginosa A-16 grown on different media was compared (Table I). Strong betaine aldehyde dehydrogenase activity was found in acetylcholine-, choline-, and betainegrown cells. No activity was detected in the cells grown on glucose medium. When only choline was added as the sole nitrogen source, small amount of activity was found in the presence of glucose and glycerol.

\section{Purification of the enzyme}

All steps were performed at $5^{\circ} \mathrm{C}$. Potassium phosphate buffer ( $\mathrm{pH} 7.4$ ) containing $0.01 \%$ 2-mercaptoethanol was used and centrifugation was carried out at $12,000 \mathrm{~g}$ for $20 \mathrm{~min}$ through the purification procedure, unless
Table I. Effects of Carbon and Nitrogen Sources on Betaine Aldehyde Dehydrogenase

Each compound was added to the basal medium at a concentration of $2 \%(\mathrm{w} / \mathrm{v})$ except for choline or $\mathrm{NH}_{4} \mathrm{Cl}$ was employed as sole nitrogen source at the concentration of $0.5 \%(\mathrm{w} / \mathrm{v})$. The basal medium consisted of 10 mmoles of $\mathrm{KCl}, 1$ mmole of $\mathrm{Na}_{2} \mathrm{SO}_{4}$, 0.4 mmole of $\mathrm{MgSO}_{4}, 40$ mmoles of $\mathrm{Na}_{2} \mathrm{HPO}_{4}$ and 22 mmoles of $\mathrm{NaH}_{2} \mathrm{PO}_{4}$ in 1-liter deionized water. $P$. aeruginosa A-16 was cultured for $24 \mathrm{hr}$ or $48 \mathrm{hr}$ at $28^{\circ} \mathrm{C}$. The assay of the enzyme activity was carried out as described in Materials and Methods.

\begin{tabular}{lcc}
\hline \multirow{2}{*}{$\begin{array}{c}\text { Carbon and nitrogen } \\
\text { source }\end{array}$} & \multicolumn{2}{c}{ Specific activity $\left(10^{-3}\right)$} \\
\cline { 2 - 3 } & 24-hr cells & 48 -hr cells \\
\hline Acetylcholine & 15.7 & 16.0 \\
Choline & 5.7 & 10.0 \\
Betaine & 10.0 & 7.9 \\
Sarcosine & 1.6 & 0.4 \\
Glycine & 0.4 & 0.4 \\
Glucose $+\mathrm{NH}_{4} \mathrm{Cl}$ & 0.0 & 0.0 \\
Glucose $+\mathrm{Choline}_{\text {Glycerol }+\mathrm{NH}_{4} \mathrm{Cl}}$ & $-a)$ & 0.6 \\
Glycerol $+\mathrm{Choline}_{\text {Succinate }+\mathrm{NH}_{4} \mathrm{Cl}}$ & -.5 & 0.3 \\
Succinate + Choline & 1.2 & 6.0 \\
\hline
\end{tabular}

a) Growth was barely observed.

otherwise stated.

1. Preparation of cell-free extract. The washed cells (about $650 \mathrm{~g}$ as dry weight), suspended in 3.0 liters of $0.1 \mathrm{M}$ buffer, were disrupted with $500-\mathrm{ml}$ portions of the suspension for $30 \mathrm{~min}$ with a Kaijo-denki $19 \mathrm{kHz}$ ultrasonic oscillator. A cell-free extract was obtained by centrifugation as supernatant.

2. Ammonium sulfate fractionation. The extract diluted to 5 liters with $0.01 \mathrm{M}$ buffer was brought to 0.3 saturation with solid ammonium sulfate. The $\mathrm{pH}$ of the solution was kept between 7.2 to 7.6 by dropwise addition of $9 \%$ ammonium hydroxide. After 30 min of stirring, the precipitate formed was removed by centrifugation. The supernatant fraction was brought to 0.7 saturation with ammonium sulfate, followed by stirring and centrifugation. The precipitate collected was suspended in $0.1 \mathrm{M}$ of the buffer (1.05 liters) and dialyzed against the buffer ( 7 liters) for $48 \mathrm{hr}$ with 5 changes. A precipitate that 
developed during dialysis was removed by centrifugation.

3. Chromatography on DEAE-cellulose. The dialyzed material was applied onto a DEAEcellulose column $(5 \times 60 \mathrm{~cm})$ previously equilibrated with $0.1 \mathrm{M}$ buffer. After washing the column with 3.0 liters of the same buffer, the enzyme was eluted with $0.3 \mathrm{M} \mathrm{NaCl}$ in $0.1 \mathrm{M}$ buffer. The active fractions were combined (600 ml).

4. Ammonium sulfate fractionation. The enzyme solution $(600 \mathrm{ml})$ was brought to 0.3 saturation by adding $137 \mathrm{~g}$ of solid ammonium sulfate, and centrifuged. To the supernatant solution obtained was added solid ammonium sulfate to bring to 0.5 saturation, and the solution was centrifuged again. The precipitate fraction was suspended in $0.1 \mathrm{M}$ buffer $(154 \mathrm{ml})$ and dialyzed against $0.1 \mathrm{M}$ buffer (7 liters) for $24 \mathrm{hr}$ with 4 changes.

5. Chromatography on DEAE-Sephadex. The dialysate was applied to a DEAE-Sephadex column $(4.0 \times 30 \mathrm{~cm})$ equilibrated with $0.1 \mathrm{M}$ buffer. After washing the column with 1.0 liter of $0.1 \mathrm{M}$ buffer, the enzyme was eluted with $0.2 \mathrm{M}$ sodium chloride in $0.1 \mathrm{M}$ buffer. Active fractions $(128 \mathrm{ml})$ were combined, and the active component was precipitated at 0.5 saturation of ammonium sulfate.

6. Chromatography of Sephadex G-200. The precipitate was dissolved in $1.5 \mathrm{ml}$ of $0.1 \mathrm{M}$ buffer and the solution was placed on a Sephadex G-200 column $(2.5 \times 75 \mathrm{~cm})$ previously equilibrated with the same buffer, and gel filtration was performed at a flow rafe of $6 \mathrm{ml} / \mathrm{hr}$ with the buffer (Fig. 1). Active fractions showing the specific activities higher than $610 \times 10^{-3}$ were combined and concentrated by the addition of ammonium sulfate ( 0.5 saturation).

7. Isoelectric focusing. After dialysis of the concentrated enzyme against 4 liters of the buffer, isoelectric focusing was performed using a 110-ml column, which was set up

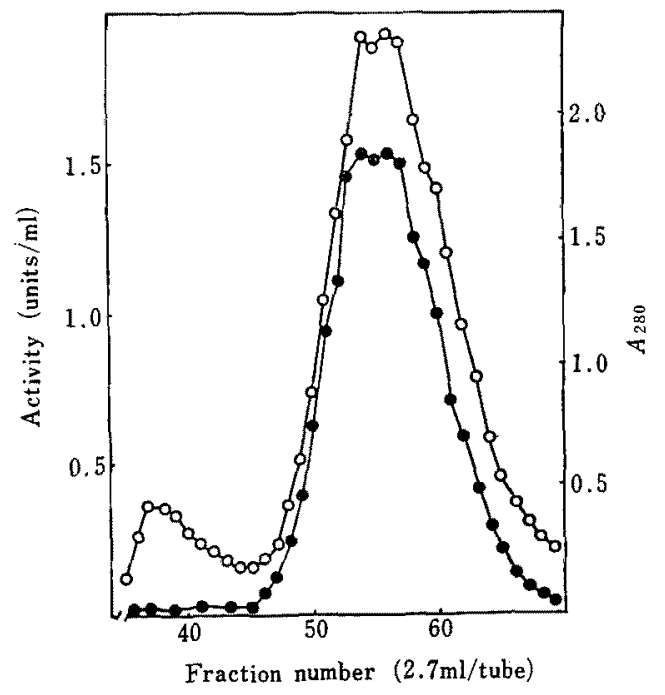

Fig. 1. Elution Diagram of the Fractionation of the Bacterial Betaine Aldehyde Dehydrogenase on Sephadex G-200.

Experimental details are described in the text. 0 , absorbance at $280 \mathrm{~nm}$;, , enzyme activity.

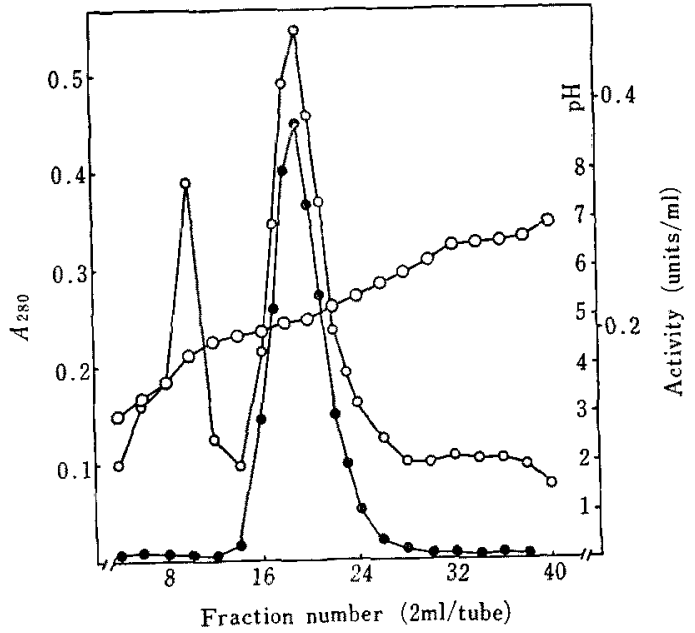

Fig. 2. Isoelectric Focusing of Betaine Aldehyde Dehydrogenase.

Enzyme applied, $7.8 \mathrm{mg} ; 300 \mathrm{~V}, 3.5 \mathrm{~mA}$ for the first $10 \mathrm{hr}$, then $500 \mathrm{~V}, 2 \mathrm{~mA}$ for the last $30 \mathrm{hr}$ at $4^{\circ} \mathrm{C}$. $\mathrm{O}$, absorbance at $280 \mathrm{~nm}$; enzyme activity; $\mathrm{O}-\mathrm{O}$, $\mathrm{pH}$.

according to the method of Vesterberg. ${ }^{12}$ ) Experiments were run at $4^{\circ} \mathrm{C}$, using $0.8 \%$ Ampholite at $\mathrm{pH}$ in a range of $3 \sim 10$. Focusing was generally performed at 500 volts and was allowed to proceed until no further 
Table II. Purification of Betaine Aldehyde Dehydrogenase FROM Pseudomonas aeruginosa A-16

\begin{tabular}{lccccc}
\hline \multicolumn{1}{c}{ Step } & $\begin{array}{c}\text { Total protein } \\
(\mathrm{mg})\end{array}$ & $\begin{array}{c}\text { Total activity } \\
\text { (units) }\end{array}$ & $\begin{array}{c}\text { Specific activity } \\
\left(10^{-3} \text { units/mg protein) }\right.\end{array}$ & $\begin{array}{c}\text { Purification } \\
\text { (fold) }\end{array}$ & $\begin{array}{c}\text { Yield } \\
(\%)\end{array}$ \\
\hline Crude extract & 348,000 & 441.9 & 1.27 & 1.0 & 100 \\
Ammonium sulfate & 63,900 & 341.9 & 5.35 & 4.2 & 77.3 \\
$\quad(30 \sim 70 \%)$ & & & & & \\
DEAE-Cellulose & 4,650 & 196.8 & 42.3 & 33.3 & 44.5 \\
Ammonium sulfate & 2,570 & 187.0 & 72.8 & 57.3 & 42.3 \\
$\quad(30 \sim 50 \%)$ & & & & & \\
DEAE-Sephadex & 140 & 53.7 & 384 & 302 & 12.2 \\
Sephadex G-200 & 73 & 45.7 & 630 & 497 & 10.3 \\
Isoelectric focusing & 15 & 11.8 & 788 & 621 & 2.6 \\
\hline
\end{tabular}

decrease in amperage was noted. Usually $40 \mathrm{hr}$ were required for it.

When focusing was complete, the column effluent was collected in 2-ml fractions which were assayed for betaine aldehyde dehydrogenase, absorbance at $280 \mathrm{~nm}$ and $\mathrm{pH}$. The betaine aldehyde dehydrogenase-containing fractions having constant specific activity (788 $\times 10^{-3}$ ) were combined and dialyzed 8 to $12 \mathrm{hr}$ against $0.1 \mathrm{M}$ buffer in order to partially remove the ampholytes and sugar. The resultant enzyme preparation was stored at $4^{\circ} \mathrm{C}$. Before use, remaining ampholytes were removed by extensive dialysis against 4 changes of the buffer. As seen in Fig. 2, the betaine aldehyde dehydrogenase and inactive protein in the Sephadex G-200 filtrate were resolved

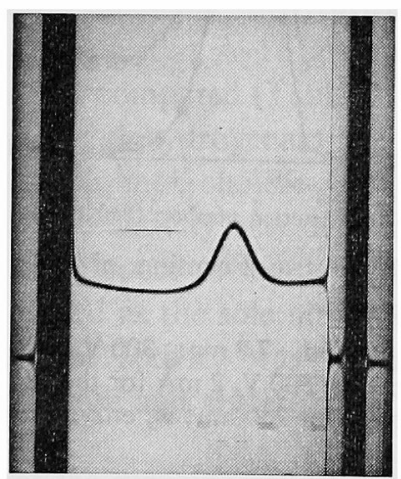

FIG. 3. Sedimentation Pattern of Betaine Aldehyde Dehydrogenase.

Protein concentration was $7.2 \mathrm{mg} / \mathrm{ml}$ in $0.01 \mathrm{M}$ potassium phosphate buffer $(\mathrm{pH} 7.4)$ containing $0.005 \%$ 2-mercaptoethanol. The photograph was taken at bar angle of $70^{\circ}$ at $32 \mathrm{~min}$ after achieving to the top speed $(59,780 \mathrm{rpm})$. by isoelectric focusing. The isoelectric point of betaine aldehyde dehydrogenase as determined by isoelectric focusing is 5.1 .

The purification of betaine aldehyde dehydrogenase from a typical preparation is summarized is Table II. Approximately $15 \mathrm{mg}$ of the final enzyme preparation can be obtained from $348 \mathrm{~g}$ of the crude extract.

\section{Homogeneity}

The specific activity after isoelectric focusing was constant across the activity peak (tube number 16 to 20). The pooled isoelectric-focused material gave a single component in the analytical ultracentrifuge (Fig. 3). Sedimentation coefficient, $s_{20, \mathrm{w}}$ was $8.3 \mathrm{~S}$.

\section{Absorption spectrum}

The absorption spectrum of betaine aldehyde dehydrogenase $(0.5 \mathrm{mg}$ per $\mathrm{ml})$ was measured at a range of wave length of 250 to $600 \mathrm{~nm}$. Only a single absorption peak at $280 \mathrm{~nm}$ could be found. The lack of a visible spectrum indicates that the betaine aldehyde dehydrogenase isolated is not a flavoprotein, nor does it contain bound form NAD as does glyceraldehyde 3-phosphate dehydrogenase.

\section{Molecular weight}

Gel filtration technique through Sephadex G-200 was used to estimate the molecular weight of the purified enzyme. The molecular weight of the enzyme was calculated to be about 145,000 . 


\section{Stability}

When the enzyme was dialyzed for 5 days against $0.1 \mathrm{M}$ buffer ( $\mathrm{pH} \mathrm{7.4)}$ at $4^{\circ} \mathrm{C}$, almost full activity was retained. When stored at $-20^{\circ} \mathrm{C}$ in the same buffer solution, practically no loss of activity was observed during the storage for at least 3 weeks.

Thermal stability of the enzyme was measured as follows: After heat treatment at various temperatures for $7 \mathrm{~min}$ in $0.01 \mathrm{M}$ phosphate buffer ( $\mathrm{pH} 7.4$ ) containing $0.01 \%$ 2-mercaptoethanol, the residual activity was determined. The treatment at $40^{\circ} \mathrm{C}$ inactivated $50 \%$, and above $50^{\circ} \mathrm{C}$ the enzyme was completely inactivated.

When the enzyme solution was incubated for $15 \mathrm{hr}$ at various $\mathrm{pHs}$, the enzyme was stable between pH 5.0 and $\mathrm{pH} 7.5$, but $60 \%$ and $80 \%$ of the original activity was lost at $\mathrm{pH} 8.0$ and $\mathrm{pH} 4.5$, respectively.

\section{Effect of $p H$ on reaction rate}

As shown in Fig. 4, the reaction rate of the dehydrogenase increased accompanying with continuous increase in $\mathrm{pH}$ from 6.0 to approximately 9.0 ; above $\mathrm{pH} 9.0$ the rate decreased markedly.

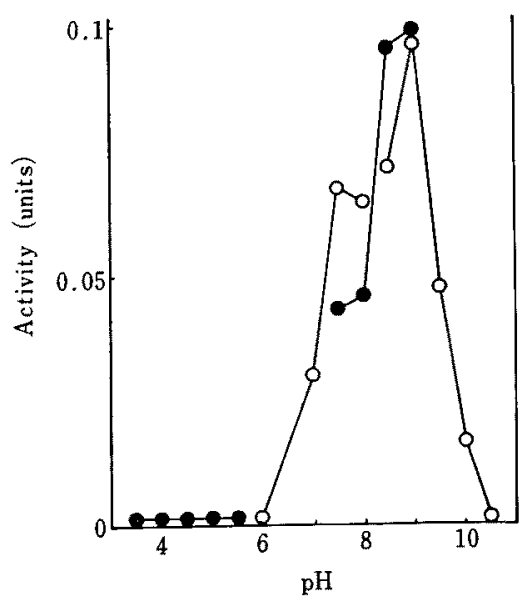

FIG. 4. Effect of $\mathrm{pH}$ on Betaine Aldehyde Dehydrogenase.

Following buffers were used: Sodium citrate-HCl buffer (e) for $\mathrm{pH} 3.5$ to $\mathrm{pH} 5.5$; Potassium phosphate buffer (O) for $\mathrm{pH} 6.0$ to 8.0 ; Tris-HCl buffer (๑) for $\mathrm{pH} 7.5$ to 9.0 ; glycine- $\mathrm{NaOH}$ buffer $(\mathrm{O})$ for $\mathrm{pH} 8.5$ to $\mathrm{pH} 10.5$.

The enzyme activity was measured under the standard condition.

\section{Effect of metal ions and various reagents}

The effects of various metal ions and other compounds on the dehydrogenase activity were examined. After preincubation with test compound for $3 \mathrm{~min}$ at $30^{\circ} \mathrm{C}$, the dehydrogenase activity was assayed. $\mathrm{Ca}^{2+}, \mathrm{Co}^{2+}$, $\mathrm{Mg}^{2+}, \mathrm{Na}^{+}, \mathrm{Fe}^{3+}, \mathrm{Mn}^{2+}, \mathrm{Li}^{+}$and $\mathrm{NH}_{4}^{+}$as chloride salts had little or no effect at a concentration of $3 \mathrm{~mm}$. However, $\mathrm{AgNO}_{3}$, $\mathrm{ZnCl}_{2}, \mathrm{CuSO}_{4}$ and $\mathrm{HgCl}_{2}$ caused $90 \sim 100 \%$ inhibition at the same concentration, and furthermore an appreciable loss in the enzyme activity was detected with $\mathrm{SH}$-reagents such as $p$-chloromercuribenzoate $(10 \mu \mathrm{M})$, iodoacetic acid $(1 \mathrm{mM})$ and mercuric acetate $(1 \mathrm{mM})$. The inactivated activity was throughly restored by the addition of 2-mercaptoethanol of a final concentration of $10 \mathrm{~mm}$. However, the addition of glutathione or cysteine at a concentration of $10 \mathrm{~mm}$ restored only $8 \%$ and $3 \%$ of the original activity, respectively.

Chelating agents such as EDTA, $o$-phenanthroline, sodium diethyldithiocarbamate, 2,2'bipvridvl and sodium azide caused no inhibition at the concentration of $1 \mathrm{~mm}$.

\section{Inhibition studies}

A study of small molecules bearing resembl-

Table III. EfFect of Various Compounds on Betaine Aldehyde Derrydrogenase

Each compound was added to the standard reaction mixture containing 0.75 unit of enzyme, and incubated for $5 \mathrm{~min}$. The reaction was initiated by the addition of NADP.

\begin{tabular}{lcc}
\hline \multicolumn{1}{c}{ Compound } & \multicolumn{2}{c}{ Inhibition (\%) } \\
\cline { 2 - 3 } & $1 \mathrm{mM}$ & $10 \mathrm{mM}$ \\
\hline Tetramethylamine iodide & - & 19 \\
Tetraethylamine iodide & - & 19 \\
Tetrapropylamine iodide & 14 & 43 \\
Benzyltrimethylamine iodide & - & 45 \\
Acetylcholine & - & 18 \\
Choline & - & 23 \\
Betaine & - & 14 \\
Sarcosine & - & - \\
Acetaldehyde & 12 & 69 \\
Glutaraldehyde & 33 & 83 \\
Isobutylaldehyde & 56 & 93 \\
$n$-Butylaldehyde & 63 & 96 \\
\hline
\end{tabular}

--: Inhibition was barely observed. 
ance to substrate or product were tested as an inhibitor of the dehydrogenase reaction (Table III). Quaternary ammonium salts, choline, betaine and acetylcholine were found to be inhibitory at a concentration of $10 \mathrm{~mm}$.

Acetaldehyde, glutaraldehyde, isobutylaldehyde and $n$-butylaldehyde showed inhibitory effect on the bacterial betaine aldehyde dehydrogenase.

\section{Substrate specificity}

The enzyme activity towards various substrates at the concentration of $5 \times 10^{-3} \mathrm{M}$ was examined by measuring the production of NADPH in the standard reaction condition containing 0.8 unit of enzyme. The dehydrogenase was highly specific to betaine aldehyde. Aliphatic aldehydes such as acetaldehyde, chloroaldehyde, propylaldehyde, $n$ butylaldehyde, isobutylaldehyde and isovaleraldehyde and a variety of aldehydes such as crotonaldehyde, chloral hydrates, glutaraldehyde, glycolaldehyde, acrolein, benzaldehyde, xanthine, D-glucose and D-mannose were not hydrogenated.

The apparent Michaelis constant estimated from double reciprocal plots was $3.8 \times 10^{-4} \mathrm{M}$ for betaine aldehyde at $\mathrm{pH} 7.4$ and $30^{\circ} \mathrm{C}$ (Fig. 5a).

The reduction with betaine and NADPH as substrates was not detected at $\mathrm{pH} 6.0$ to 9.5 and at various concentration of betaine and NADPH.

\section{Coenzyme specificity}

NAD and NADP functioned as coenzyme of this enzyme reaction. The apparent Michaelis constants for NAD and NADP were determined to be $2.2 \times 10^{-4} \mathrm{M}$ and $8.9 \times 10^{-5} \mathrm{M}$ in the presence of $1 \mathrm{~mm}$ betaine aldehyde, respectively (Fig. $5 \mathrm{~b}$ and $5 \mathrm{c}$ ).

\section{DISCUSSION}

$P$. aeruginosa $\mathrm{A}-16$ and $P$. polycolor IFO 3918 were capable of growing on acetylcholine and butyrylcholine, respectively, as sole carbon and nitrogen source. ${ }^{13)}$ We have attempted
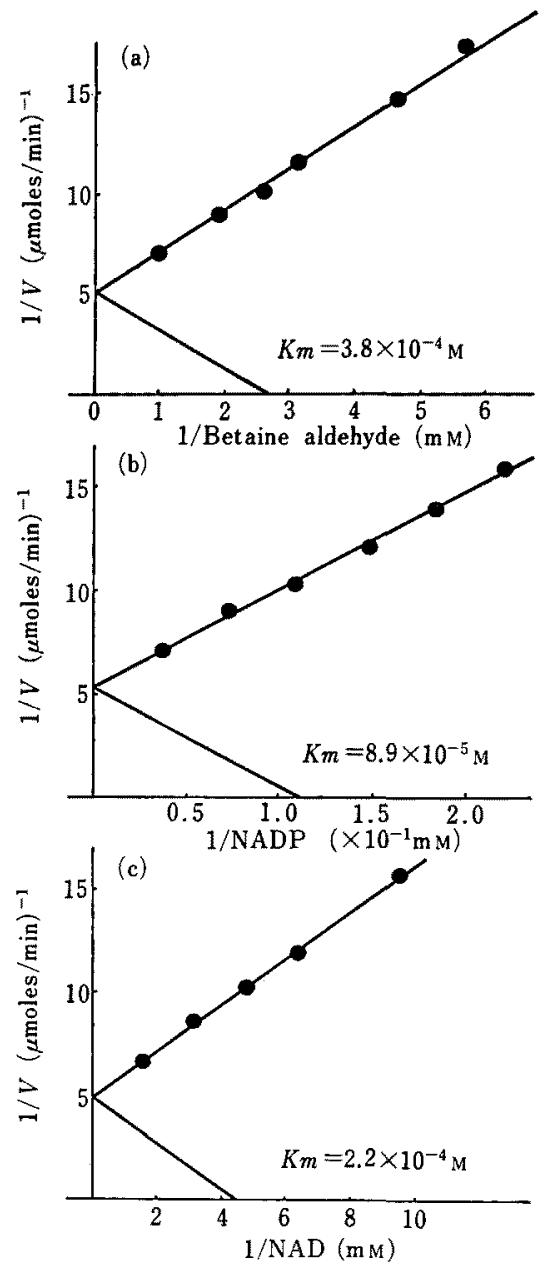

Fig. 5. Double Reciprocal Plots by Betaine Aldehyde Dehydrogenase of $P$. aeruginosa A-16.

The experiments were carried out under the standard condition. (a) betaine aldehyde, (b) NADP, (c) NAD.

to make clear the biochemical system for decomposition of choline esters. The first step in the decomposition was the cleavage of the ester-bond by acetylcholinesterase or butyrylcholinesterase found in the cells of $P$. aeruginosa $\mathrm{A}-16^{14)}$ or $P$. polycolor, respectively. ${ }^{15}$ The second step in the decomposition was the oxidation of choline to betaine aldehyde by choline dehydrogenase, which was detected in the cell-free particulate fraction of $P$. aeruginosa A-16. ${ }^{8}$ Furthermore the presence of betaine aldehyde dehydrogenase in the cells of $P$. aeruginosa A-16 grown on the choline medium supports that choline was 
metabolized to betaine via betaine aldehyde. Thus, the bacterium requires two enzymes, choline dehydrogenase and betaine aldehyde dehydrogenase, as the mammalian liver does, although choline is directly oxidized to betaine in the intact cells of Achromobacter cholinophagum. $^{\text {s) }}$

From the results that betaine aldehyde dehydrogenase, acetylcholinesterase and choline dehydrogenase were inducibly formed in the presence of acetylcholine, choline and betaine in the culture medium, and that the distributions of cholinesterase activity and choline-utilizing activity overlapped each other in pseudomonads belonging to fluorescent group, ${ }^{13)}$ these three enzymes might be formed together, relating to the decomposition of acetylcholine.

The betaine aldehyde dehydrogenase was active towards only betaine aldehyde among various aldehydes tested. The enzyme was inhibited by some aldehydes such as $n$-butylaldehyde or some quaternary ammonium salts, therefore the high specificity of the enzyme might be conceivably due to the attachment through its aldehyde and quaternary nitrogen group of betaine aldehyde.

As the enzyme was not effected by chelating reagents, dialysis treatment, and the addition of some metal ions, there was not question to the importance of metal ions in the reaction systems of the enzyme, whereas the addition of magnesium chloride was effective for maximal activity of the mammalian liver betaine al- dehyde dehydrogenase. ${ }^{9 /}$

The great difference of coenzyme requirement was seen between the bacterial enzyme and the mammalian enzyme. Though the mammalian enzyme required only NAD as coenzyme, ${ }^{9}$ both NADP and NAD functioned equally in the bacterial enzyme system.

\section{REFERENCES}

1) H. A. Rothschild, O. Cori and E. S. G. Barron, J. Biol. Chem., 208, 41 (1954).

2) I. C. Wells, ibid., 207, 575 (1954).

3) J. N. Williams, Jr. and A. Screenivasan, ibid., 203, 899 (1953).

4) L. Packer, R. W. Estabrook, T. P. Singer and T. Kimura, ibid., 235, 535 (1960).

5) F. Bernheim and M. L. C. Bernheim, Am. J. Physiol., 121, 55 (1938).

6) H. S. Shieh, Can. J. Biol., 10, 837 (1964).

7) G. J. J. Korstee, Arch. Microbiol., 71, 235 (1970).

8) T. Nagasawa, Y. Kawabata, Y. Tani and K. Ogata, Agr. Biol. Chem., 39, 1513 (1975).

9) H. A. Rothschild and E.S. Guzmann Barron, J. Biol. Chem., 209, 511 (1954).

10) O. H. Lowry, N. J. Rosebrough, A. L. Farr and R. J. Randall, ibid., 193, 263 (1951).

11) P. Andrews, Biochem. J., 96, 595 (1965).

12) O. Vesterberg, "Methods in Enzymology," Vol. XXII, ed by W. B. Jackoby, Academic Press Inc., New York, N. Y., 1971, p. 389.

13) Y. Tani, T. Nagasawa, H. Oda and K. Ogata, Agr. Biol. Chem., 39, 105 (1975).

14) Y. Tani, T. Nagasawa, H. Sugisaki and K. Ogata, ibid., 39, 1287 (1975).

15) T. Nagasawa, H. Sugisaki, Y. Tani and K. Ogata, Biochim. Biophys. Acta, 429, 817 (1976). 